\title{
PENGARUH KONSENTRASI LARUTAN URIN KAMBING SEBAGAI MEDIA PENYIRAMAN DAN PUPUK ORGANIK TERHADAP PRESENTASE PERKECAMBAHAN, PERSENTASE KECAMBAH NORMAL DAN PRODUKSI HIJAUAN SEGAR PADA FODDER JAGUNG (Zae mays) DENGAN SISTEM HIDROPONIK
}

\author{
Tri Ida Wahyu Kustyorini ${ }^{1}$, Aju Tjatur Nugroho Krisnaningsih ${ }^{1}$, Wempilianus Bai Ria ${ }^{1}$ \\ ${ }^{1}$ Fakultas Peternakan, Universitas Kanjuruhan Malang \\ triida@unikama.ac.id
}

\section{ABSTRAC}

The purpose of this study was to determine the effect of goat urine concentration as watering media and organic fertilizer on the percentage of germination, percentage of normal germination and fresh forage production. The material used in this study was 250 corn seeds per unit. The research method used was a field experiment using a completely randomized design (CRD) with 4 treatments and 5 replications. The treatments performed were P0 Watering $100 \%$ water, P1 watering 5\% goat urine solution, P2 watering 10\% goat urine solution, P3 watering $15 \%$ goat urine solution, and P4 watering $20 \%$ goat urine. Based on the results of the study showed that the concentration of goat urine solution as a watering medium and organic fertilizer had a very significant effect $(\mathrm{P}<0.01)$ on the percentage of germination, percentage of normal germination, fresh forage production. The highest percentage of germination in P1 treatment with a value of $64.88 \%$, the highest percentage of normal germination in P1 treatment with a value of $96.87 \%$, and the highest fresh forage production in P1 treatment with a value of 138.8 grams. The conclution of the research were the frequency of seeding twice a day giving the highest productivity of corn (Zea mays) with hydroponic systems.

keywords: watering media, organic fertilizer, corn fodder, hydrophonic.

\section{Pendahuluan}

Hijauan merupakan sumber pakan utama bagi ternak ruminansia untuk memenuhi kebutuhan hidup pokok. Oleh karena itu yang dapat menjadi solusi untuk pemenuhan kebutuhan pakan dengan memproduksi hijauan berkesinambungan tanpa dipengaruhi oleh musim. Ketersediaan bahan pakan merupakan hal yang paling penting dalam menunjuang usaha peternakan. Pakan hijauan adalah kebutuhan pokok yang tidak dapat dihindarkan bagi ternak ruminansia. Kebutuhan ternak ruminansia akan pakan hijauan sebanding dengan jumlah populasi ternak yang berkembang sekarang, pengembangan pakan hijauan ternak hanya memungkinkan jika dilaksanakan di daerah-daerah yang masih jarang penduduknya. Akan tetapi pada kawasan yang padat penduduk, lahan untuk pengembangan pakan hijauan ternak harus berkompetisi dengan tanaman pangan, misalnya padi dan ketela.

Hijauan merupakan sumber bahan pakan utama bagi ternak ruminansia untuk memenuhi kebutuhan hidup pokok, fodder dapat dijadikan sebagai pakan hijauan. Hidroponik adalah salah satu istilah yang digunakan untuk bercocok tanam tanpa menggunakan tanah sebagai media tanamnya serta mengunakan capuran nutrisi esensial yang dilarutkan di dalam air (Sodarmojo, 2008). 


\section{Jurnal Sains Peternakan}

Volume 7 No. 2, Desember 2019, pp:135-140

ISSN 2579-445

Jagung (Zea mays) merupakan salah satu tanaman pangan dunia yang terpenting, selain gandum dan padi. Jagung merupakan salah satu serealia yang stratergis dan bernilai ekonomi serta mempunyai peluang untuk dikembangkan karena kedudukannya sebagai pakan. Produktifitas fodder jagung dipengaruhi oleh faktor internal (hormon dan genetik) dan faktor eksternal adalah iklim, ketersediaan unsur hara, dan kadar air.

Urin kambing merupakan bahan organik yang sangat bermanfaat, dengan sedikit pengolahan urin kambing dapat di ubah menjdai pupuk organik cair yang sangat berguna bagi tanaman. Pengolahan urin kambing sangat di perlukan untunk meningkatakan unsurhara dalam pupuk organik cair supaya dapat memenuhi kebutuhan unsur hara tanaman dan meningkatkan kesuburan tanah. Marmut mengkonsumsi pakan hijau dengan kadar air dan toleransi serat kasar cukkup tinggi sehingga lebih mudah dalam pemberian pakan dan perawatan.

Hidroponik folder jagung merupakabn salah satu teknik tanam yang dapat yang dijadikan sebagain solusi untuk penyediaan hijauan bagi ternak ruminansia, karena dengan sistem hidroponik penanaman dapat dilakukan sepanjang tahun tanpa di pengaruhi oleh musin sehingga dapat mengatasi kekurangan pakan hijauan khususnya saat musim kemarau (Prihartini,2013).

Urin merupakan salah satu fitohormon alami yang mengandung hormon dari golongan auksin, gibberellin dan sitokinin. Secara fisiologis fitohormon berfungsi dalam perkembangan dan diferensiasi sel yang dapat memacu pertumbuhan organ-organ tanaman, seprti akar, tunas dan meristem apikal lainnya. Respon fitohormon tersebut akan berlangsung pada konsentrasi yang rendah $<10$ ppm dan bila diberikan dalam konsentrasi yang tiggi maka fitohormon tersebut akan bersifat merusak atau penghambat pertumbuhan (Adrian dan Murniati, 2007). Penelitian Kustyorini et al (2019) menyatakan bahwa tingkat keberhasilan stek rumput gajah dengan perendaman pada larutan urin kambing 10\% selama 40 menit memberikan nilai terbaik senilai 97,78\%.

\section{Materi Dan Metode}

Materi yang digunakan dalam penelitian ini yaitu biji jagung sebanyak 250 biji per unit ulangan, urin kambing dan air.

Percobaan metode yang dilakukan dalam penelitian ini adalah percobaan lapang dengan menggunakan rancangan acak lengkap, (RAL). Dengan konsentrasi larutan urin kambing sebagai perlakuan yaitu:

- $\mathrm{PO}: 0 \%$ urin+100\% air

- P1 : 5\% urin + 95\% air 


\section{Jurnal Sains Peternakan}

Volume 7 No. 2, Desember 2019, pp:135-140

ISSN 2579-445

- $\mathrm{P} 2: 10 \%$ urin $+90 \%$ air

- $\quad$ P3 : $15 \%$ urin $+\% 85 \%$ air

Variabel yang diamati dalam penelitian ini meliputi variabel bebas yaitu konsentrasi larutan urin kambing, dan variabel terikat antara lain presentase perkecambahan, peresentase kecambah normal dan produksi segar.

Persentase perkecambahan benih diamati dengan metode benih yang berkecambah pada setiap unit pencobaan. Pengamatan dilakukan pada hari ke 5 budi daya tanaman.

Dengan rumus:

$$
\text { \%perkecambahan }=\frac{\Sigma \text { jumlah benih yang berkecambah }}{\Sigma \text { benih }} x 100 \%
$$

Pengamatan dilakukan terhadap kecambah normal pada akhir penelitian tepatnya 14 hari setelah benih ditanam, dengan cara membongkar media kemudian kecambah diambil dan dilakukan pengamatan selanjutnya. Presentase kecambah normal dihitung dengan cara, Sari dan Saati (2003) sebagai berikut:

$$
\text { \%kecambah normal }=\frac{\Sigma \text { kecambah normal }}{\Sigma \text { kecambah }} \times 100 \%
$$

Produksi segar adalah makanan yang berasal dari hijauan dan diberikan keternak dalam bentuk segar. Produksi hijauan dengan cara melakukan penanaman hijauan tiap kontak kemudian dilakukan perhitungan tiap ulangan saat panen, mencakup akar, batang dan daun dihitung dengan satuan $(\mathrm{kg})$ (Herdiawan, 2013).

Semua data kuantitatif dianalisis menggunakan analisis varian, jika ada terdapat pengaruh dilanjurtkan dengan uji BNT.

\section{Hasil Dan Pembahasan}

Berdasarkan hasil penelitian menunjukan bahwa dalam perlakuan penyiraman pada biji jagung dengan konsentrasi larutan urin kambing yang berbeda memberikan pengaruh sangat nyata $(\mathrm{P}<0,01)$ terhadap persentase perkecambahan, persentase kecambah normal dan produksi hijauan segar.

\section{Persentase Perkecambahan}

Berdasarkan hasil analisa sidik ragam menunjukkan bahwa konsentrasi larutan urin kambing sebagai media penyiraman dan pupuk organik memberikan pengaruh yang sangat nyata $(\mathrm{P}<0,01)$ terhadap persentase perkecambahan fodder jagung (Zea mays) dengan sistem hidroponik. Sarah dkk, (2016) menyatakan bahwa standar persentase perkecambahan $80 \%$ hasil tersebut dapat menjadi acuan untuk melakukan penanaman pada fodder jagung. Rata-rata persentase perkecambahan dapat di lihat pada Tabel 1. 


\section{Jurnal Sains Peternakan}

Volume 7 No. 2, Desember 2019, pp:135-140

ISSN 2579-445

Tabel 1. Rata-Rata Persentase Perkecambahan.

\begin{tabular}{lr}
\hline Perlakuan & Persentase Perkecambahan $(\%)$ \\
\hline PO & $61,68 \pm 1,89^{\mathrm{c}}$ \\
P1 & $64,88 \pm 3,73^{\mathrm{c}}$ \\
P2 & $55,2 \pm 1,35^{\mathrm{b}}$ \\
P3 & $47,2 \pm 1,82^{\mathrm{a}}$ \\
P4 & $43,76 \pm 3,44^{\mathrm{a}}$ \\
\hline
\end{tabular}

Keterangan: notasi ${ }^{\mathrm{a}-\mathrm{c}}$ yang berbeda pada kolom yang sama menunjukkan perbedaan yang sangat nyata $(\mathrm{P}<0,01)$.

Persentase perkecambahan yang tertinggi pada perlakuan P1 yang menggunakan konsentrasi larutan urin kambing 5\% dengan nilai $(64,88 \%)$ sedangkan persentase perkecambahan terendah pada perlakuan P4 yang menggunakan konsentrasi larutan urin kambing 20\% dapat menghasilkan nilai 43,75\%. Hal ini di karenakan pada penggunaan konsentrasi 5\% memiliki kadar fitohormon yang optimal, pada perlakuan P2-P4 mengalami penurunan persentase perkecamabahan, dikarenakan dosis fitohormon yang terkandung melebihi kebutuhan. Nilai ini lebih rendah dari hasil penelitian Kustyorini, dkk (2018) persentase perkecambahan hidroponik fodder jagung dengan perendaman pada larutan kambing memberikan nilai $81,67 \%$.

Konsentrasi larutan urin kambing sebanyak 5\% mampu memberi pengaruh terbaik dikarenakan konsentrasi larutan urin 5\% mampu di absobsi biji dan akar tanaman dengan baik. Hal ini di karenakan larutan urin kambing sebagai pupuk cair bermanfaat untuk meningkatkan kandungan fitohormon hara pada tanaman. Fitohormon yang terkandung dalam urin diantaranya adalah auksin, giberelin dan sitokinin.

\section{Persentase Kecambah Normal}

berdasarkan hasil perhitungan rata-rata persentase tingkat keberhasilan terendah dengan penyiraman dua kali perhari mencapai rata-rata 93,69\%, dan hasil perhitungan yang tertinggi mencapai rata-rata 96,87\%. Standar kecambah normal $70 \%$ dan menyatakan jika penyiraman dilakukan tidak sesui maka pertumbuhan benih tersebut akan bersifat merusak atau menghambat pertumbuhan. Nilai ini lebih tinggi dari hasil penelitian Kustyorini, dkk (2018) persentase kecambah normal hidroponik fodder jagung dengan perendaman pada larutan kambing memberikan nilai 90,00\%. Data hasil persentase kecambah normal dapat dilihat pada tabel 2 .

Tabel 2. Standar Persentase Kecambah Normal

\begin{tabular}{lr}
\hline Perlakuan & Persentase kecambahan normal $(\%)$ \\
\hline P0 & $96,79 \pm 1,17^{\mathrm{b}}$ \\
P1 & $96,87 \pm 0,91^{\mathrm{b}}$ \\
P2 & $94,65 \pm 1,03^{\mathrm{a}}$ \\
P3 & $94,75 \pm 0,68^{\mathrm{a}}$ \\
P4 & $93,69 \pm 1,85^{\mathrm{a}}$ \\
\hline
\end{tabular}




\section{Jurnal Sains Peternakan}

Volume 7 No. 2, Desember 2019, pp:135-140

ISSN 2579-445

Keterangan: notasi ${ }^{\mathrm{a}-\mathrm{b}}$ yang berbeda pada kolom yang sama menunjukkan perbedaan yang sangat nyata $(\mathrm{P}<0,01)$.

P1 memberikan nilai tertinggi dikarenakan kadar fitohormon pada larutan urin kambing 5\% sesuai dengan kebutuhan fitohormon pada tanaman. Hal ini sesuai dengan pendapat Heddy (1990) Penggunaan urin 10\%,15\%,20\% mulai mengalami penurunan persentase kecambah normal dikarenakan kerja hormon auksin sinergis dengan hormon sitokinin dan hormon giberelin pertumbuhan di sinari oleh matahari maka pertumbuhannya akan lambat, karena kerja auksin di hambat oleh matahari tapi sisi tumbuhan yang tidak di sinari oleh cahaya matahari prtumuhannya sangat cepat karena kerja auksin tidak di hambat, sehingga akan menyebabkan ujung tanaman tersebut cenderung mengikuti arah sinar matahari atau yang disebut dengan fototropisme.

\section{Produksi Hijauan Segar}

Berdasarkan analisa sidik ragam menunjukan bahwa penyiraman biji jagung dengan air dan larutan urin kambing memberikan pengaruh yang sangat nyata $(\mathrm{P}<0,01)$ terhadap hasil produksi hijauan segar, berdasarkan hasil perhitungan rata-rata produksi hijauan segar terlihat bahwa hasil terendah P4 mencapai 61,4 gram dan hasil tertinggi pada P1 138,8 gram. Data hasil produksi hijauan segar dapat dilihat pada tabel 3.

Tabel 3. Standar Rata-rata Produksi Hijauan Segar

\begin{tabular}{lc}
\hline Perlakuan & Produksi Hijauan Segar (gram) \\
\hline P0 & $99,2 \pm 7.19^{\mathrm{d}}$ \\
P1 & $138,8 \pm 8,70^{\mathrm{e}}$ \\
P2 & $84,8 \pm 6,46^{\mathrm{c}}$ \\
P3 & $75 \pm 4,12^{\mathrm{b}}$ \\
P4 & $61,4 \pm 5,77^{\mathrm{a}}$ \\
\hline
\end{tabular}

Keteranga: notasi ${ }^{\text {a-e }}$ yang berbeda pada kolom yang sama menunjukkan perbedaan yang sangat nyata $(\mathrm{P}<0,01)$.

Hal ini dikarenakan persentase perkecambahan, persentase kecambah normal pada perlakuan P1 memberikan nilai tertinggi,sehingga tanaman yang tumbuh pada perlakuan tersebut lebih banyak. Konsentrasi 5\% dalam larutan urin kambing untuk penyiraman memberikan nilai terbaik,di karenakan fitohormon yang terkandung sesuai kebutuhan tanaman, hasil ini sangat baik dengan tercapainya 138,8gram. Nilai ini lebih tinggi jika dibanding dengan penelitian Kustyorini, dkk (2019) yakni produksi hijauan segar hidroponik fodder jagung dengan penyiraman menggunakan larutan urin sapi 5\% sebesar 138 gram. 


\section{Jurnal Sains Peternakan}

Volume 7 No. 2, Desember 2019, pp:135-140

ISSN 2579-445

\section{Kesimpulan}

Berdasarkan hasil penelitian yang disimpulkan konsentrasi larutan urin kambing sebagai media penyiraman dan pupuk organik 5\% memberikan nilai terbaik terhadap persentase perkecambahan $(64,88 \%)$, persentase kecambah normal $(96,87 \%)$ dan produksi hijauan segar (138,8 gram).

\section{Daftar Rujukan}

Adrian dan Murniati. 2007. Pemanfaatan Urin Sapi Pada Setek Batang Tanaman Jarak Pagar (Jatropa Curcas L.). Sagu 16: No. 2: 1-8

Heddy, S. 1990. Biologi Pertanian. Rajawali Press. Jakarta.

Herdiawan I. 2013. Pertumbuhan tanaman pakan ternak leguminosa pohon Indigofera zollingeriana pada berbagai taraf perlakuan cekaman kekeringan. JITV. 18:258264

Kustyorini, T. I. W., D. P. P. Hadiyani and H. Rohman, 2019. The Effect Of Different Stem Immersion Duration On Goat Urine Solution On Success Rate Of Elephant Grass Cuttings (Pennisetum purpureum). Journal of Physics: Conference Series. Annual Conference of Science and Technology. IOP Publishing.

Kustyorini, T. I. W., A. T. N. Krisnaningsih dan D. Z. Hanif. 2019. Pengaruh konsentrasi larutan urin sapi sebagai media Penyiraman dan pupuk organik terhadap persentase Perkecambahan, persentase kecambah normal dan Produksi hijauan segar pada hidroponik Fodder Jagung (Zea mays). Jurnal Sains Peternakan. Vol 7 No. 1. Hal 47-53.

Prihartini, I. 2013. Identifikasi Performans Sapi Madura sebagai Karakteristik Sifat Genetik dalam Upaya Seleksi Produktivitas Ternak Unggul. Jurnal protein 17:1078-1079

Sarah., Rahmatan H., Supriatno. 2016. Standar keberhasilan perkecambahan benih untuk dibudidayakan. Jurnal Ilmiah Mahasiswa Pertanian, Universitas hasanudin Makasar. Volume 1, Issue 1, Agustus 2016, hal 1-9.

Sari, D. P., dan Saati, E. A. 2003. Pengujian Efektivitas Penggunaan Jenis Pelarut dan Asam dalam Ekstraksi Pigmen Antosianin Bunga Kanan. Skripsi. Jurusan THP, Fakultas Pertanian. Universitas Muhammadiyah Malang

Sudarmodjo. 2008. Hidroponik. Tidak dipublikasikan. Parung Farm, Bogor. 